\title{
Development and Validation of a Stability indicating Related Substances of Baricitinib by RP-HPLC and its Degradation
}

\author{
S. Mohan, N. Srinivasarao, K. Lakshmi
}

\begin{abstract}
Reverse phase high performance liquid chromatography method, for estimation of related substances or chromatographic impurities of Barcitinib was developed and validated. Baricitinib was developed by separating its degradation products on a X-Terra RP18 $(150 \times 4.6 \mathrm{~mm}, 5.0 \mu \mathrm{m})$ column using $0.1 \%$ Tri ethyl amine in water adjusted $\mathrm{pH}-2.5$ with $\mathrm{OPA}$ and Acetonitrile in simple gradient at a flow rate $1.0 \mathrm{ml} / \mathrm{min}$. The column effluents were monitored by a photodiode array detector set at 224nm. The method was validated in terms of specificity, linearity, accuracy, precision, detection limit, quantification limit and robustness. Forced degradation of Baricitinib was carried out under acidic, basic, peroxide, reduction, thermal, photo and hydrolysis conditions. The proposed method is validated as per ICH Q2 (R1) guidelines. The proposed method is simple as selected chromatographic conditions are not so difficult to apply in routine analysis for testing the chromatographic impurity of baricitinib.
\end{abstract}

Keywords: Baricitinib, RP-HPLC, Related substances, Chromatographic impurity.

\section{INTRODUCTION}

Baricitinib is a drug for the treatment of rheumatoid arthritis ${ }^{1}$ being developed by Incyte ${ }^{2}$ and Eli Lily ${ }^{3}$. Baricitinib is an orally bio available inhibitor of Janus kinases $4 \quad 1 \quad$ and 2 (JAK1/2), with potential anti-inflammatory, immunomodulat ing and antineoplastic ${ }^{5}$ activities. Upon administration, baricitinib binds to JAK1/2 activation and leads to the inhibition of the JAK-signal transducers and activators of transcription (STAT) signaling pathway. This decreases the production of inflammatory cytokines ${ }^{6}$ and may prevent an inflammatory response. In addition baricitinib may induce apoptosis ${ }^{7}$ and haematopoiesis ${ }^{8}$ they are also unregulated and/or mutated in various tumor ${ }^{9}$ cell types.

Baricitinib is an orally bio available small molecule inhibitor of Janus kinases 10 that is used to treat moderate-to-severe rheumatoid 11 arthritis. Baricitinib is associated with transient and usually mild elevations in serum aminotransferase ${ }^{12}$ levels during therapy but has yet to be linked to cases of clinically apparent acute liver injury.

Revised Manuscript Received on October 10, 2019.

* Correspondence Author

Dr. Mohan Seelam*, Department of chemistry, Bapatla Engineering College, Bapatla, India. Email: seelam.mohan@gmail.com

Dr. Srinivasa Rao Nathani, Department of chemistry, Bapatla Engineering College,Bapatla, India. Email: nathanisrinivasarao@gmail.com

K.Lakshmi, Department of chemistry, Tirumala Engineering College, Narasarao pet, India. Email: lakshmisrinivas41@gmail.com

(C) The Authors. Published by Blue Eyes Intelligence Engineering and Sciences Publication (BEIESP). This is an open access article under the CC BY-NC-ND license (http://creativecommons.org/licenses/by-nc-nd/4.0/)

\section{MATERIALS AND REQUIREMENTS}

Instrument

HPLC, make: Waters alliance e-2695 chromatographic system consisting of quaternary pump, PDA detector-2996 and chromatographic software Empower-2.0 was used.

Reagents

$\mathrm{CH}_{3} \mathrm{CN}$ (HPLC grade), $\mathrm{H}_{3} \mathrm{PO}_{4}$ (HPLC grade), $\mathrm{H}_{2} \mathrm{O}$ (HPLC grade).

Mobile Phase Preparation

Mobile Phase-A: $1 \mathrm{ml}$ Orthophospharic acid is transferred into 1 lt water. Filter through membrane $(0.45 \mu)$ and degas.

Mobile Phase-B: $\mathrm{CH}_{3} \mathrm{CN}$

Preparation of diluent: 50:50 v/v. of mobile phase-A and mobile phase-B were mixed.

Optimization of mobile phase

Different trails have done, different buffers and different mobile phases were used to develop the method. In all trails peaks are not separated properly. Finally for the proposed method all the peaks are separated and the entire suitability conditions are within the limit.

Table-I: Gradient Program

\begin{tabular}{|c|c|c|}
\hline Time (min) & Mobile Phase-A & Mobile Phase-B \\
\hline 0.00 & 80 & 20 \\
\hline 5 & 50 & 50 \\
\hline 7 & 50 & 50 \\
\hline 8 & 80 & 20 \\
\hline 12 & 80 & 20 \\
\hline
\end{tabular}

Chromatographic conditions

The chromatographic system was carried out in symmetry C18, $(150 \times 4.6 \mathrm{~mm}, 3.5 \mu \mathrm{m})$ column. Flow rate was maintained at $1.0 \mathrm{ml} / \mathrm{min}$ injection volume is $10 \mu \mathrm{l}$ and sample and column temperatures are ambient. Wavelength detection is maintained at $265 \mathrm{~nm}$.



Fig. 1. PDA Spectra for Baricitinib and its impurities Standard Solution

Published By:

Blue Eyes Intelligence Engineering \& Sciences Publication 
Accurately weigh Baricitinib (100.3mg). The working standard is transferred into a volumetric flask $(100 \mathrm{ml})$ add $70 \mathrm{ml}$ of $50: 50 \mathrm{v} / \mathrm{v}$. of mobile phase-a and mobile phase-b sonicated for $10 \mathrm{~min}$ to dissolve the contents make up to the mark with 50:50 v/v. of mobile phase-a, and mobile phase-b. Further $5 \mathrm{ml}$ of above solution to $50 \mathrm{ml}$ with diluent.

Sample Solution

Transfer 500.2mg of sample into a $100 \mathrm{ml}$ volumetric flask diluted to volume with diluent. Filter through $0.45 \mu$ nylon syringe filter.

Impurity standard stock solution

Weigh accurately impurity-1(50mg), impurity-2(250mg) and impurity-3 (100mg) and taken into a $100 \mathrm{ml}$ volumetric flask. Add $70 \mathrm{ml}$ of 50:50 v/v. of mobile phase-a, and mobile phase-b, sonicated to dissolve and make up.

Spiked Sample Solution

Transfer $10 \mathrm{ml}$ of sample into a volumetric flask $(100 \mathrm{ml})$ add add $1 \mathrm{ml}$ of impurity standard stock solution and $70 \mathrm{ml}$ of makeup to the mark with 50:50 v/v. of mobile phase-a, and mobile phase-b. Filter through $0.45 \mu$ syringe filter.

\section{RESULTS AND DISCUSSION}

Validation of proposed method

The proposed method was validated for parameters like, specificity, linearity, LOD, LOQ, precision, accuracy, robustness and ruggedness as per ICH guidelines ${ }^{\text {[13-14] }}$.

System Suitability

The HPLC system was stabilized for $60 \mathrm{~min}$ to get a stable baseline. Six replicate injections of standard solution were injected. The results are summarized below Table II.

Table- II: System Suitability Data

\begin{tabular}{|l|l|l|}
\hline $\begin{array}{l}\text { System } \\
\text { Suitability } \\
\text { parameter }\end{array}$ & $\begin{array}{l}\text { Acceptance } \\
\text { criteria }\end{array}$ & Drug Name \\
\cline { 3 - 3 }$\%$ RSD & NMT 2.0 & Baricitinib \\
\hline USP Tailing & NMT 2.0 & 1.03 \\
\hline $\begin{array}{l}\text { USP Plate } \\
\text { Count }\end{array}$ & NLT 3000 & 50637 \\
\hline
\end{tabular}



Fig. 2. Chromatogram for System suitability Specificity

There is no interaction of peaks in blank and standard, sample, placebo chromatograms in the total runtime of chromatogram. Hence its proves that method is specific.



Fig 3. Chromatogram for Blan

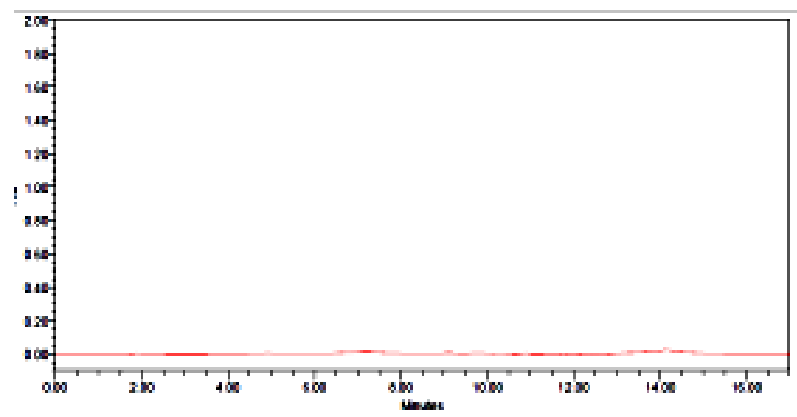

Fig 4: Chromatogram for Placebo

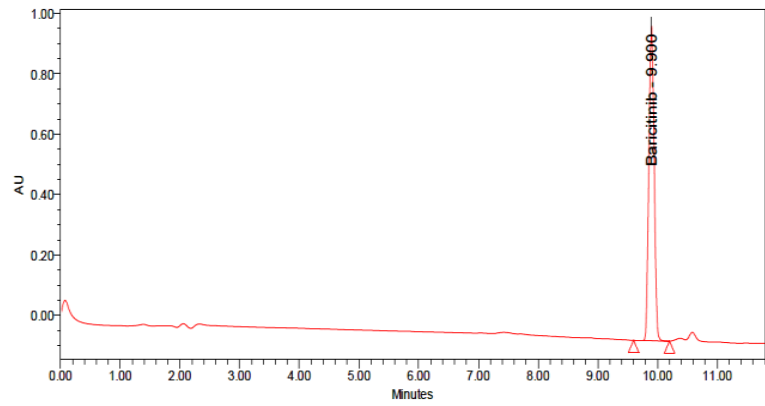

Fig 5: Chromatogram for Standard

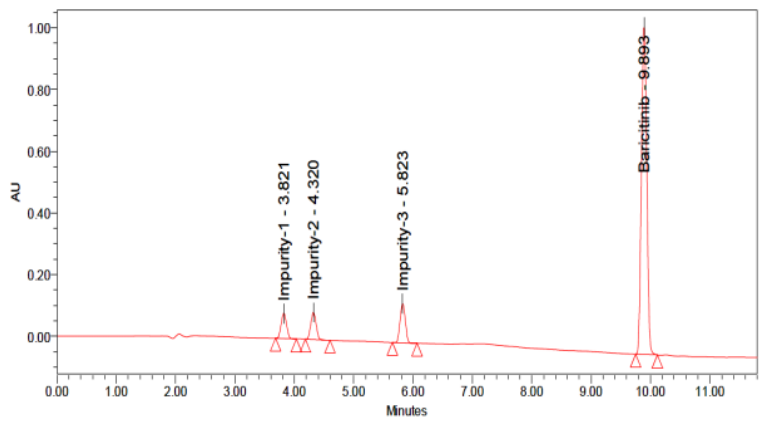

Fig6: Chromatogram for Sample

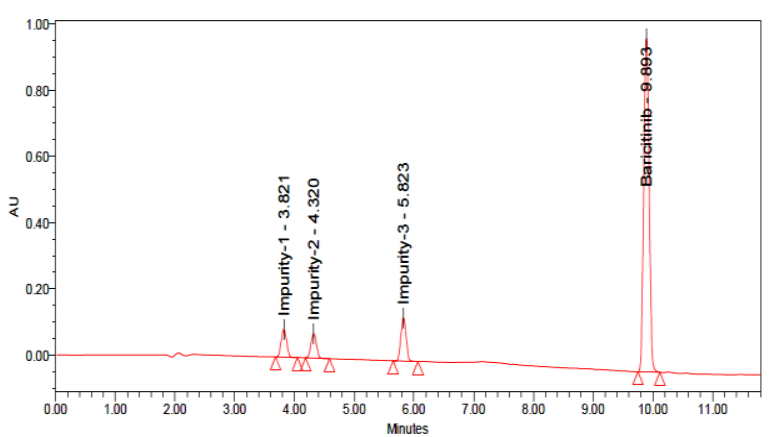

Fig 7: Chromatogram for spiked sample solution and $\mathrm{Hu}_{\mathrm{r}}$






\section{Linearity}

The linearity was observed in the concentration range of $10-150 \mu \mathrm{g} / \mathrm{ml}$ for Baricitinib. The regression equation is $\mathrm{Y}=57232 \mathrm{X}+161136$ and correlation coefficient was found to be 0.99949 . Impurity-1 concentration range from $0.5 \mu \mathrm{g} / \mathrm{ml}$ to $7.5 \mu \mathrm{g} / \mathrm{ml}$, regression equation is $\mathrm{Y}=5170 \mathrm{X}+3724.8$ and correlation coefficient were found to be 0.99918 . Impurity-2 concentration range from $0.5 \mu \mathrm{g} / \mathrm{ml}$ to $7.5 \mu \mathrm{g} / \mathrm{ml}$ regression equation is $\mathrm{Y}=4502 \mathrm{X}+3574.5$ and correlation coefficient were found to be 0.99933 . Impurity-3 concentration range from $1-15 \mu \mathrm{g} / \mathrm{ml}$ regression equation is $\mathrm{Y}=7577 \mathrm{X}+9140.4$ and correlation coefficient was found to be 0.9995



Fig 8: Linearity plot for Baricitinib



Fig 9: Linearity plot for Impurity-1



Fig 10: Linearity plot for Impurity-2

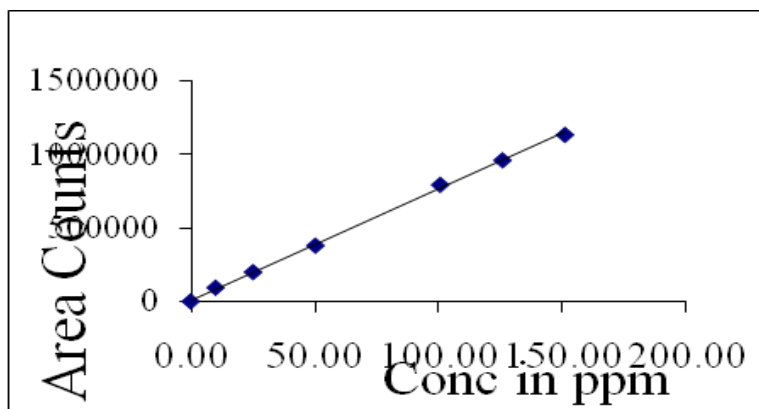

Fig 11: Linearity plot for Impurity-3

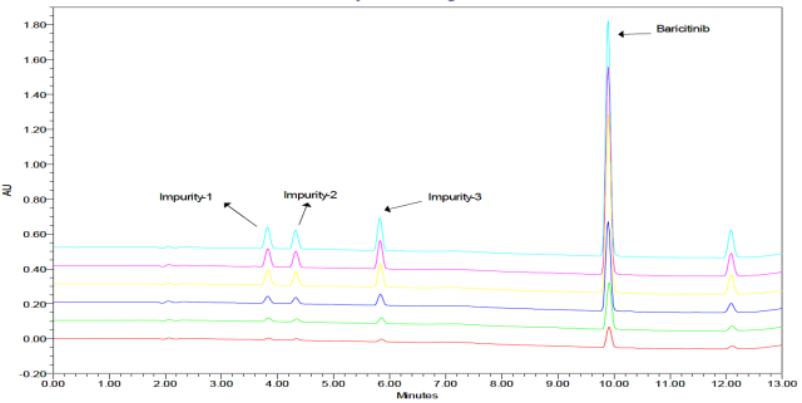

Fig 12: Overlay chromatogram for Linearity

Accuracy

The accuracy of the related substances test procedure was determined by spiking of Baricitinib and impurities stock solution to test the sample. So that the concentration of the impurity would be $0.5 \%$ of the test concentration as per the test method. Injecting samples in triplicate at 50\%, 100\% and $150 \%$ of the target concentration. The recovery results should be NLT $95.0 \%$ and NMT $105.0 \%$.

Table -III: Accuracy results for Baricitinib

\begin{tabular}{|c|c|c|c|}
\hline S.No. & $\%$ Level & $\begin{array}{l}\% \\
\text { Recovery }\end{array}$ & Avg. \%Recovery \\
\hline 1 & \multirow[b]{3}{*}{50} & 100.4 & \multirow[b]{3}{*}{100.2} \\
\hline 2 & & 100.1 & \\
\hline 3 & & 100 & \\
\hline 4 & \multirow[b]{3}{*}{100} & 100.3 & \multirow[b]{3}{*}{100.1} \\
\hline 5 & & 100.2 & \\
\hline 6 & & 99.9 & \\
\hline 7 & \multirow[b]{3}{*}{150} & 100.5 & \multirow[b]{3}{*}{100.4} \\
\hline 8 & & 100.7 & \\
\hline 9 & & 100.1 & \\
\hline
\end{tabular}

Table IV: Accuracy results for Impurity-1

\begin{tabular}{|c|c|c|c|}
\hline S.No. & \% Level & $\begin{array}{c}\% \\
\text { Recovery }\end{array}$ & Avg. \%Recovery \\
\hline 1 & \multirow[b]{3}{*}{50} & 100.2 & \multirow[b]{3}{*}{100.7} \\
\hline 2 & & 100.2 & \\
\hline 3 & & 100.6 & \\
\hline 4 & \multirow[b]{3}{*}{100} & 99.9 & \multirow[b]{3}{*}{100.1} \\
\hline 5 & & 100.1 & \\
\hline 6 & & 100.3 & \\
\hline 7 & \multirow[b]{3}{*}{150} & 100.1 & \multirow[b]{3}{*}{100.6} \\
\hline 8 & & 100 & \\
\hline 9 & & 100.8 & \\
\hline
\end{tabular}


Development and Validation of a Stability indicating Related Substances of Baricitinib by RP-HPLC and its Degradation

Table V Accuracy results for Impurity-2

\begin{tabular}{|c|c|c|c|}
\hline S.No. & \% Level & \% Recovery & $\begin{array}{c}\text { Avg. } \\
\text { \%Recove } \\
\text { ry }\end{array}$ \\
\hline 1 & \multirow{3}{*}{50} & 100.3 & \multirow{3}{*}{100.1} \\
\hline 2 & & 99.9 & \\
\hline 3 & & 100.0 & \\
\hline 4 & \multirow{3}{*}{100} & 100.6 & \multirow{3}{*}{100.5} \\
\hline 5 & & 100.2 & \\
\hline 6 & & 100.6 & \\
\hline 7 & \multirow{3}{*}{150} & 100.7 & \multirow{3}{*}{100.5} \\
\hline 8 & & 100.7 & \\
\hline 9 & & 100.2 & \\
\hline
\end{tabular}

Table VI : Accuracy results for Impurity-3

\begin{tabular}{|c|c|c|c|}
\hline S.No. & \% Level & \% Recovery & Avg. \%Recovery \\
\hline 1 & \multirow[b]{3}{*}{50} & 100.3 & \multirow[b]{3}{*}{100.3} \\
\hline 2 & & 100.5 & \\
\hline 3 & & 100.1 & \\
\hline 4 & \multirow[b]{3}{*}{100} & 99.9 & \multirow[b]{3}{*}{100.1} \\
\hline 5 & & 100.2 & \\
\hline 6 & & 100.1 & \\
\hline 7 & \multirow[b]{3}{*}{150} & 99.9 & \multirow[b]{3}{*}{100.1} \\
\hline 8 & & 100.1 & \\
\hline 9 & & 100.4 & \\
\hline
\end{tabular}

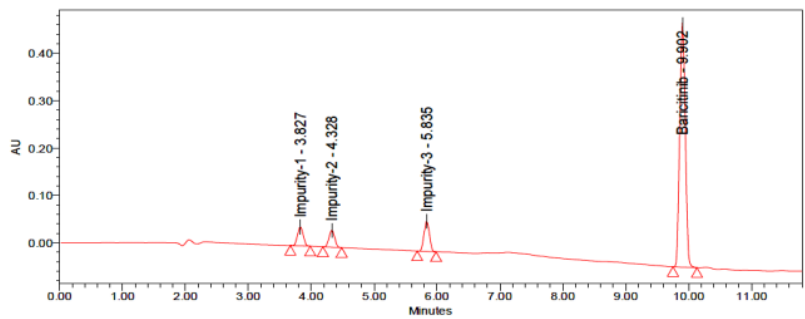

Fig 13: Chromatogram for Accuracy 50\%

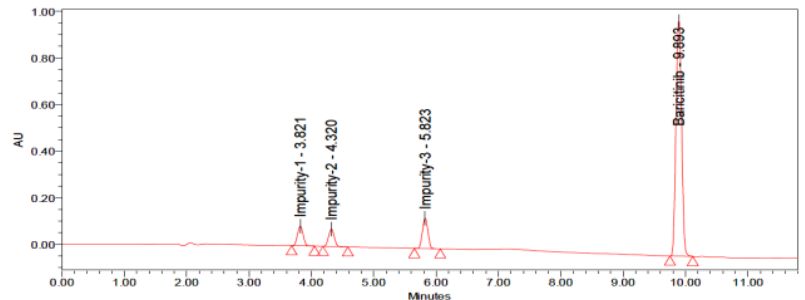

Fig 14: Chromatogram for Accuracy 100\%

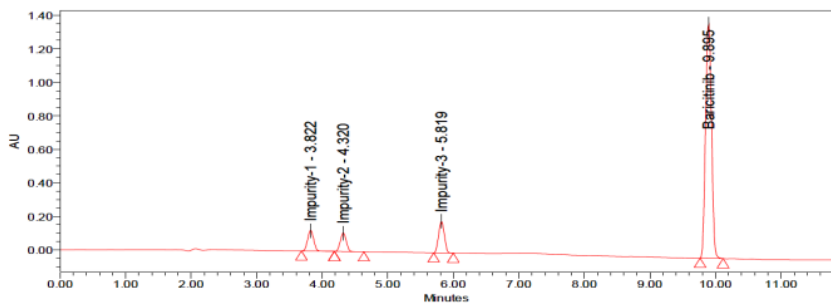

Fig 15: Chromatogram for Accuracy 150\%

\section{Precision}

Precision of the test method was determined by repeatability assessed using a minimum of 6 determinations and calculated $\%$ relative standard deviation of impurities. The results were given in Table 7 . Related substances results meet the specification limits.
Table VII: Precision results for Baricitinib

\begin{tabular}{|c|c|c|}
\hline \multirow{2}{*}{ Sample No. } & \multicolumn{2}{|c|}{ \% of Related Substances } \\
\cline { 2 - 3 } & Total Impurities & $\begin{array}{c}\text { \% Purity } \\
\text { (100-Total Imp.) }\end{array}$ \\
\hline 1 & 0.13 & 99.87 \\
\hline 2 & 0.16 & 99.84 \\
\hline 3 & 0.10 & 99.90 \\
\hline 4 & 0.14 & 99.86 \\
\hline 5 & 0.17 & 99.83 \\
\hline 6 & 0.14 & 99.86 \\
\hline Average & 0.14 & 99.88 \\
\hline \%RSD & 0.18 & 0.15 \\
\hline
\end{tabular}

Intermediate Precision

Six replicates of a sample solution were analysed on a different day, different analyst and different instrument. Peak areas were calculated which were used to calculate mean, \% RSD values. The results are given below table VIII

Table VIII: Precision results for Baricitinib

\begin{tabular}{|c|c|c|}
\hline \multirow{2}{*}{ Sample No. } & \multicolumn{2}{|c|}{ \% of Related Substances } \\
\cline { 2 - 3 } & Total Impurities & $\begin{array}{c}\text { \% Purity } \\
\text { (100-Total Imp.) }\end{array}$ \\
\hline 1 & 0.18 & 99.82 \\
\hline 2 & 0.14 & 99.86 \\
\hline 3 & 0.09 & 99.91 \\
\hline 4 & 0.12 & 99.88 \\
\hline 5 & 0.15 & 99.85 \\
\hline 6 & 0.10 & 99.90 \\
\hline Average & 0.15 & 99.85 \\
\hline \%RSD & 0.13 & 0.69 \\
\hline
\end{tabular}

\section{LOD and LOQ}

LOD and LOQ were separately determined by calibration curve method ${ }^{[15]}$. LOD and LOQ of the compound were determined by injecting progressively lower concentrations of standard solutions using developed RP-HPLC method. The LOD concentrations for Baricitinib and their impurities-1, 2, 3 are $0.0515,0.0505,0.52,0.051 \mu \mathrm{g} / \mathrm{ml}$ their $\mathrm{s} / \mathrm{n}$ values are $3,3,4,7$. The LOQ concentration for Baricitinib and their impurities-1, 2, 3 are $0.103,0.101,0.104,0.102$ $\mu \mathrm{g} / \mathrm{ml}$ their s/n values are 22,22,24,28.



Fig 16: Chromatogram for LOD

Published By:

(1) 10

\& Sciences Publication

(C) Copyright: All rights reserved. 


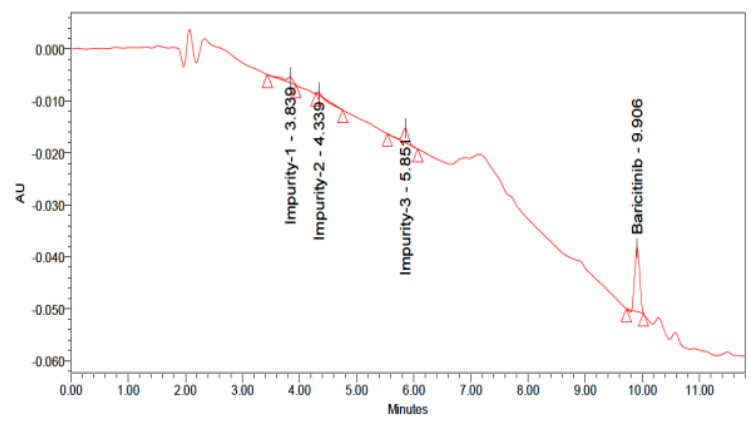

Fig 17: Chromatogram for LOQ

\section{Robustness}

The robustness of the method was evaluated by analyzing the system suitability standards and evaluating system suitability parameter data after varying the HPLC pump flow rate $( \pm 0.2$ $\mathrm{ml})$ and organic solvent content $( \pm 10 \%)$. The alterations caused a significant change in peak area R.S.D (\%), USP tailing factor and retention times

Table 9: Robustness data

\begin{tabular}{|c|c|}
\hline \multirow{2}{*}{ Parameter name } & \% RSD for Purity \\
\cline { 2 - 2 } & Baricitinib \\
\hline Flow $(0.8 \mathrm{ml} / \mathrm{min})$ & 0.155 \\
\hline Flow $(1.2 \mathrm{ml} / \mathrm{min})$ & 0.201 \\
\hline Organic solvent (+20\%) & 0.201 \\
\hline Organic solvent (-20\%) & 0.147 \\
\hline
\end{tabular}

\section{Stability}

The stability of Baricitinib in solution was determined by sample solution stability initial to $24 \mathrm{hr}$ at different time intervals at room temperature and $2-8^{\circ} \mathrm{C}$. There is no significant deviation of purity. Difference between initial to $24 \mathrm{hr} \pm 9.0 \%$.

Table 10: Results for Solution Stability

\begin{tabular}{|c|c|c|}
\hline Stability & $\begin{array}{c}\text { Purity of } \\
\text { Baricitinib }\end{array}$ & \% of Deviation \\
\hline Initial & 99.99 & 0.00 \\
\hline $12 \mathrm{Hr} \mathrm{RT}$ & 99.96 & 0.03 \\
\hline $12 \mathrm{Hr} 2-8^{\circ} \mathrm{C}$ & 99.95 & 0.04 \\
\hline $24 \mathrm{Hr} \mathrm{RT}$ & 99.98 & 0.01 \\
\hline $24 \mathrm{Hr} 2-8^{\circ} \mathrm{C}$ & 99.97 & 0.02 \\
\hline
\end{tabular}

\section{Forced Degradation}

Acid Degradation:

$10 \mathrm{ml}$ of sample transferred into a $100 \mathrm{ml}$ volumetric flask add $10 \mathrm{ml}$ of $0.1 \mathrm{~N} \mathrm{HCl}$ heat for $15 \mathrm{~min}$ at $60^{\circ} \mathrm{C}$ after that add $10 \mathrm{ml}$ of $0.1 \mathrm{~N} \mathrm{NaOH}$ then makeup to mark with diluent. Then the solution is filter through $0.45 \mu$ nylon syringe filter.

Alkali Degradation:
$10 \mathrm{ml}$ of sample transferred into a $100 \mathrm{ml}$ volumetric flask add $10 \mathrm{ml}$ of $0.1 \mathrm{~N} \mathrm{NaOH}$ heat for $15 \mathrm{~min}$ at $60^{\circ} \mathrm{C}$ after that add $10 \mathrm{ml}$ of $0.1 \mathrm{~N} \mathrm{HCl}$ then makeup to the mark with diluent. Then the solution is filter through $0.45 \mu$ nylon syringe filter.

Peroxide Degradation:

$10 \mathrm{ml}$ of sample transferred into a $100 \mathrm{ml}$ volumetric flask add $5 \mathrm{ml}$ of $10 \% \mathrm{H}_{2} \mathrm{O}_{2}$ heat for $30 \mathrm{~min}$ at $60^{\circ} \mathrm{C}$ then cool to makeup with diluent. Filter the solution with $0.45 \mu$ nylon syringe filter.

Reduction Degradation:

$10 \mathrm{ml}$ of sample transferred into a $100 \mathrm{ml}$ volumetric flask add $10 \mathrm{ml}$ of $10 \%$ sodium bicarbonate solution heat for $15 \mathrm{~min}$ at $60^{\circ} \mathrm{C}$ then cool to makeup with diluent. Filter the solution with $0.45 \mu$ nylon syringe filter.

Thermal Degradation:

The sample drug solution was placed in oven at $105^{\circ} \mathrm{C}$ for $6 \mathrm{Hr}$. The resultant solution was injected into HPLC system. Photolytic Degradation:

The sample solution was exposed into sunlight for 6hr. The sample was injected into HPLC system

Table 11: Results for Forced Degradation

\begin{tabular}{|c|c|}
\hline \multirow{2}{*}{ Degradation Condition } & \% of Purity \\
\cline { 2 - 2 } & Baricitinib \\
\hline Acid Degradation & 72.31 \\
\hline Alkali Degradation & 72 \\
\hline Peroxide Degradation & 72.13 \\
\hline Reduction Degradation & 72.13 \\
\hline Thermal Degradation & 72.18 \\
\hline Photolytic Degradation & 72.07 \\
\hline
\end{tabular}

\section{CONCLUSION}

The developed method gave good resolution between Baricitinib and its 3-impurities with short runtime (12min), high efficiency and complies with modified SST specifications of USP. The use of C18 column in the present work has shown better elution of analytes with good resolution, improved plate count, tailing. So the C18 column can be used to achieve high specificity in shorter time of analysis of Baricitinib as per ICH Q3A (R2) ${ }^{[16]}$ guidelines. The proposed method was found to be simple, precise, accurate, linear, robust and rapid for simultaneous determination and quantification of Baricitinib. The sample recovery was in good agreement with their respective label claims suggested non-interference in the estimation. Hence, the method can be easily and conveniently adopted for routine analysis of Baricitinib dosage form. 


\section{REFERENCES}

1. V. Majithia, S. A. Geraci, "Rheumatoid arthritis diagnosis and management," Am. J. Med. 2007, 120 (11), 936-9.

2. Natoli, Cori Anne: Incyte looks to ride on drug success. The News Journal; 2012.

3. Lilly and Incyte Announce submission of NDA to FDA for Oral Once-Daily Baricitinib for treatment of Moderate-to-Severe Rheumatoid Arthritis. Drug.com; 2016.

4. A. Kontzias , A. Kotlyar, A. Laurence, P. Changelian , J. J. O Shea , Jakinibs, " a new class of kinase inhibitors in cancer and autoimmune disease" Current Opinion in Pharmacology , 2012, 12(4), 464-70.

5. Wood Miriam, David Brighton: the royal marsden hospital handbook of cancer chemotherapy, 2005.

6. J. G. Cannon , "Inflammatory Cytokines in No pathological States" News Physiol sci. 2000, 12(1), 150-9.

7. B. Alberts, A. Johnson A , "Apoptosis programmed cell death eliminates unwanted cells,” chapter 18. Molecular Biology of the cell. Garland Science $5^{\text {th }}$ ed. 2008, p.1115.

8. Birbrair, Alexander, Frenette, Paul S: niche heterogeneity in the bone marrow. Annals of the New York Academy of Sciences 2016, 1370:82-96.

9. A. Birbair , T. Zhang T , " Type-2 pericytes participate in normal and tumoral angiogenesis. American journal of Physiology", Cell Physiology, 2014, 307(1), C25-38.

10. S. J. Rodig, M. A. Meraz, “ Disruption of the Jak1 gene demonstrate obligatory and nonredundnat roles of the Jaks in cytokine-induced biologic responses" Cell 1998, 93(3), 373-83.

11. X. Puechal, Terrier , "Relapsing polychondritis", Joint, bone, spine revue du rhumatisme, 2014, 81(2), 118-24.

12. A. Karmen , F. Wroblewski , J. S. Ladue, " Transminase activity in human blood", The journal of clinical investigation, 1955, 34(1),126-31.

13. ICH Validation of analytical procedures methodology ICH harmonized tripartite guideline.

14. Validation of compendia methods. United states pharmacopeia, 2003, $21^{\text {st }}$ edition, 2440.

15. J.E. Parkin, “ High performance liquid chromatographic assay of menthol using indirect photometric detection", J.Chromatogr, 1984 303:436-9.

16. ICH international conference on harmonisation of technical requirements for registration of pharmaceutical for human use, impurities in new drug substances, 2006.

\section{AUTHORS PROFILE}

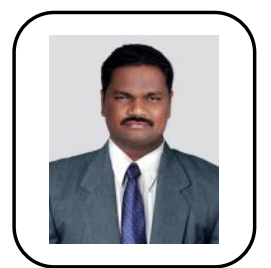

Dr. Mohan Seelam obtained Ph. D from Acharya Nagarjuna University. Currently working as Assistant Professor in the Department of Chemistry, Bapatla Engineering College, Bapatla, Guntur District, Andhra Pradesh, India.

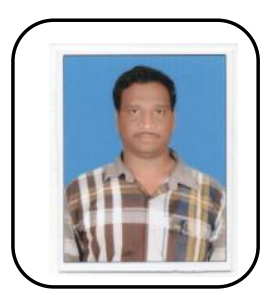

Srinivasa Rao Nathani, Ph,D Assistant Professor.Department of Chemistry. Bapatla Engineering College, Bapatla,Andhra Pradesh, India.nathanisrinisrinivasarao@gmail.com .

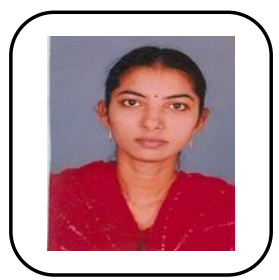

Lakshmi Kondraganti working as an Assistant professor, Science \& Humanities department in Tirumala Engineering College.,Narasaraopet and pursuing Ph.D at jawaharlal Nehru Technological University.Kakinada, Andhra Pradesh, India. 